\title{
PENGEMBANGAN KREATIVITAS ANAK MELALUI KEGIATAN EKSPLORASI
}

\author{
Faizah \\ Sekolah Tinggi Agama Islam Nahdlatul Ulama' (STAINU) Temanggung \\ e-mail: iezahahmad91@gmail.com
}

Diterima: 13 April 2019 I Direvisi: 27 Mei 2019 I Disetujui: 28 Mei 2019 (C) 2019

Pendidikan Guru Raudhatul Atfhal Fakultas Agama Islam Universitas Islam Malang

\begin{abstract}
The purpose of this study was to understand the process of developing the creativity of kindergarten-aged children through exploration activities at Pertiwi Kindergarten. It was using a qualitative descriptive research method. This research prepares, understands and analyzes exploration activities as an effort to develop children's creativity. The results of the study show; the concept of exploration activities at the Pertiwi Kindergarten was carried out as a substitute for learning activities and adapted to the theme of learning. The activity forms such as; gardening, playing water, playing sand, animal exploration, and rice harvest exploration. Its implications are children's information insight is increasingly widespread, growing love toward the environment. Children become more creative and critical, and foster an attitude of children independence and responsibility.
\end{abstract}

Keywords: Child Creativity Development, Exploration Activities.

\section{A. Pendahuluan}

Taman kanak-kanak merupakan salah satu bentuk pendidikan prasekolah yang ada di jalur pendidikan sekolah. Pendidikan prasekolah adalah pendidikan untuk membantu pertumbuhan dan perkembangan, jasmani dan rohani anak di luar lingkungan keluarga sebelum memasuki Pendidikan Dasar. Usaha ini dilakukan supaya anak usia 4-6 tahun lebih siap mengikuti pendidikan selanjutnya.

Adapun tujuan dari pada program kegiatan belajar anak taman kanak-kanak adalah untuk membantu meletakkan dasar ke arah perkembangan sikap, pengetahuan, keterampilan, dan daya cipta yang diperlukan oleh anak didik dalam menyesuaikan diri dengan lingkungannya dan untuk pertumbuhan dan perkembangan selanjutnya. Selanjutnya, sebagaimana terdapat dalam Garis-garis Besar Program Kegiatan Belajar Taman Kanak-kanak (Kemendikbud, 1994), taman kanak-kanak didirikan sebagai usaha mengembangkan seluruh segi kepribadian anak didik dalam rangka menjembatani pendidikan dalam keluarga dan

This work is licensed under Creative Commons Attribution Non Commercial 4.0 International License Available online on: http://riset.unisma.ac.id/index.php/fai/index 


\section{Faizah}

pendidikan sekolah (Rachmawati Yeni dan Kurniati Euis, 2017). Namun pada pelaksanaannya, pembelajaran cenderung bersifat "akademik", lebih menekankan pada kemampuan kognitifnya. Semiawan Conny (2002) mengatakan bahwa prestasi belajar anak tidak hanya ditentukan oleh kemampuan intelektual yang bersifat kognitif nemun dipengaruhi pula oleh faktor non-kognitif. Faktof nonkognitif seperti emosi, motivasi, kepribadian dan faktor lingkungan.

Lebih lanjut, masa kanak-kanak adalah masa yang peka untuk menerima berbagai macam rangsangan dari lingkungan guna menunjang perkembangan jasmani dan rohani yang ikut menentukan keberhasilan anak didik mengikuti pendidikannya di kemudian hari. Masa kanak-kanak dapat juga dikatakan masa bermain, oleh sebab itu kegiatan pendidikan di taman kanak-kanak diberikan melalui bermain sambil belajar, dan belajar sambil bermain. Dengan demikian, guru dituntut untuk memahami konsep dan aplikasi pengembangan kreativitas agar anak dapat tumbuh dan berkembang sesuai dengan potensi yang mereka miliki secara optimal.

Jika kita analisis dari tujuan program kegiatan belajar anak taman kanakkanak, maka dapat ditemukan satu kata kunci yang juga merupakan satu keutuhan dalam tujuan tersebut, yaitu kreativitas. Sekilas memang tidak asing dan cukup mudah untuk diterapkan, namun pada kenyataannya dalam pelaksanaan di lapangan (berbagai sekolah Taman Kanak-kanak), masih banyak ditemukan kesulitan yang berkenaan dengan bagaimana mengembangkan kreativitas pada anak taman kanak-kanak.

Kreativitas merupakan salah satu bagian dari seluruh perkembangan manusia, oleh karena itu faktor yang mempengaruhi perkembangan manusia secara keseluruhan juga secara umum berpengaruh terhadap perkembangan kreativitas individu, meskipun secara spesifik ada penekanan-penekanan tertentu pada setiap aspek perkembangan. Salah satu faktor yang mempengaruhi perkembangan kreativitas anak adalah faktor lingkungan, baik lingkungan fisik maupun sosial, baik keluarga, sekolah maupun masyarakat (Hawadi, 2001).

Lingkungan yang mampu memberikan stimulasi terhadap potensi kecerdasan anak dengan baik, dalam suasana kondusif dan menyenangkan akan membantu perkembangan kreativitas anak. Terutama lingkungan sekolah, pihak internal sekolah khususnya guru harus mampu menyajikan kegiatan pembelajaran yang menarik dan menyenangkan untuk anak.

Kreativitas pada anak-anak memiliki ciri tersendiri, tidak dapat disamakan dengan kreativitas orang dewasa. Kreativitas anak dikoridori oleh keunikan gagasan dan tumbuhnya imajinasi serta fantasi. Anak-anak yang kreatif akan sensitif terhadap stimulasi. Mereka juga tidak dibatasi oleh frame-frame apapun. 


\section{Faizah}

Dalam arti, mereka memiliki kebebasan dan keleluasaan beraktivitas. Kreativitas anak usia dini juga ditandai dengan kemampuan membentuk imajinasi mental, konsep berbagai hal yang tidak hadir di hadapannya. Anak usia dini juga memiliki fantasi, imajinasi untuk membentuk konsep yang mirip dengan dunia nyata.

Bagi anak usia kanak-kanak, mereka dikatakan kreatif ketika ia menemukan pemecahan atas permasalahan yang dihadapi. Mereka akan mempertimbangkan berbagai hal untuk memilih solusi terbaiknya. Kemudian, jika anak telah berhasil menyelesaikan masalahnya, maka ia disebut kreatif. Seperti contoh, ketika layanglayang seorang anak tersangkut di pohon. Maka ia akan mempertimbangkan cara, bagaimana supaya layang-layang yang diambil tidak sobek/rusak. Apakah akan mengunduhnya menggunakan kayu, memanjat, atau menarik-narik talinya. Begitulah anak-anak yang kreatif, mereka selalu menggunakan imajinasi ketika hendak bertindak.

Atas beberapa gambaran di atas, penulis memilih TK Pertiwi, karena saat melakukan pra-penelitian, penulis mendapati proses belajar mengajar yang unik yang diterapkan oleh guru setempat agar pembelajaran tidak hanya berpusat di dalam kelas. Untuk mengembangkan kreativitas dan menstimulasi imajinasi anakanak, guru mendesain proses pembelajaran dengan kegiatan eksplorasi. Guru melakukan pembelajaran melalui beberapa kegiatan seperti berkebun, bermain di kolam ikan, merawat tanaman, bermain lempar bola di lapangan, dan lainnya.

Penelitian ini menjadi menarik sebab beberapa alasan, yakni karena taman kanak-kanak merupakan salah satu bentuk pendidikan prasekolah yang memfasilitasi anak untuk membantu pertumbuhan dan perkembangan jasmani dan rohani anak, dan untuk membantu anak agar lebih siap mengikuti pendidikan sekanjutnya. Selain itu, letak TK Pertiwi yang berada daerah pegunungan yang cukup jauh dari perkotaan, juga menjadi alasan menarik. Kebanyakan anak-anak disana akan merasa kurang percaya diri jika disandingkan dengan anak-anak daerah perkotaan. Oleh karena itu, pengembangan kreativitas anak melalui kegiatan bereksplorasi yang diterapkan tersebut menjadi layak untuk dikembangkan sebagai wujud eksistensi kegiatan pembelajaran di taman kanakkanak.

Secara empiris, penelitian ini penting dilakukan guna mereduksi stigma negatif anak-anak yang sekolah di pedesaan akan cenderung kalah bersaing dengan sekolahan di perkotaan (realitanya, siswa TK Pertiwi seringkali memenangkan lomba Taman Kanak-kanak tingkat kecamatan hingga kabupaten). Selain itu, memberikan gambaran kepada guru taman kanak-kanak secara umum, untuk menerapkan pembelajaran berbasis eksplorasi yang menyenangkan agar 
pembelajaran tidak lagi bersifat "akademik" sekaligus agar anak mengenal lebih dekat dan mencintai lingkungan.

\section{B. Metode}

Penelitian ini menggunakan metode deskriptif kualitatif. Metode ini digunakan karena mampu menjelaskan hubungan antar kategori yang nantinya ditemukan dan disusun dalam penelitian ini. Metode kualitatif juga mampu menggambarkan dan menganalisis pola kegiatan manusia.

Penelitian ini dilakukan untuk memberikan gambaran secara lebih mendalam mengenai konsep kegiatan eksplorasi sebagai kegiatan bermain yang menyengkan dan mengedukasi untuk anak-anak di TK Pertiwi, bentuk kegiatan eksplorasi sebagai upaya pengembangan kreativitas anak sekaligus implikasinya terhadap pengembangan kreativitas anak-anak. Kegiatan mereka sehari-hari akan dinilai untuk kemudian disusun sebagai sebuah praktik pembelajaran yang memiliki tujuan untuk mengembangkan kreativitas anak-anak. Bagaimana kemudian anak-anak antusias mengikuti pembelajaran tersebut, khususnya bagaimana anak-anak secara sadar menikmati dan mengembangkan hasil dari kegiatan eksplorasi.

Terdapat tiga tipe utama pada metode pengumpulan data, meliputi data observasi, data interview, dan dokumentasi. Dalam penelitian ini, data yang digunakan berupa hasil wawancara (data interview), sehingga teknik pengumpulan data dilaksanakan melalui wawancara mendalam (depth interview) dan observasi partisipan kepada informan, hal ini dilakukan karena melalui metode inilah didapatkan gambaran dari kegiatan pengembangan kreativitas anak.

Penelitian ini menggunakan sistem peran serta lengkap, dimana peneliti menjadi pengamat dalam hal ini menjadi anggota penuh dari kelompok teramati. Dalam kaitannya dengan penelitian ini penulis mewawancarai 3 guru taman kanak-kanak, yakni utamanya kepala taman kanak-kanak setempat dan guru taman kanak-kanak setempat. Sedangkan informan dengan siswa berjumlah 10 anak, baik dari kelas rendah dan kelas atas.

\section{Hasil dan Pembahasan}

\section{Konsep Kegiatan Eksplorasi di TK Pertiwi}

Sebelum membahas lebih lanjut tentang kegiatan eksplorasi di TK Pertiwi, penulis akan menguraikan kembali tujuan dari penelitian ini, yaitu untuk memahami bagaimana proses pengembangan kreativitas anak usia taman kanak-kanak melalui kegiatan bereksplorasi. Tujuan akhir dari pada 


\section{Faizah}

penelitian ini adalah mengetahui implikasi dari kegiatan eksplorasi terhadap perkembangan kreativitas anak.

Kegiatan eksplorasi di TK Pertiwi dilaksanakan sebagai pengganti kegiatan pembelajaran dan disesuaikan dengan tema pembelajaran. Misalnya, tema pembelajarannya adalah berkebun. Maka anak-anak akan diarahkan ke kebun, mengamati orang-orang berkebun kemudian membantu dan menirukan petani berkebun. Jika temanya adalah bangunan, maka anak akan diarahkan ke halaman yang disediakan pasir beserta berbagai bentuk cetakan, ember kecil, sekop, dan lainnya. Dengan bekal gambar beberapa bagunan dari buku, anak dituntun untuk memilih cetakan bangunan yang sesuai dengan gambar kemudian bermain pasir dan membuat cetakan bangunan sesuai dengan yang mereka inginkan.

Tugas guru hanyalah sebagai pendamping dan fasilitator. Guru mendampingi anak sekaligus memberikan pemahaman terkait dengan tema eksplorasi hari itu. Siswa diberikan kebebasan berekspresi dan berekspolrasi, meskipun harus basah-basahan dengan air dan kotor oleh tanah, namun kondisi tersebut merupakan bagian dari latihan motorik kasar dan halus anak. Guru tidak dianjurkan melarang ataupun memberikan batasan dari ekspresi dan gerak anak.

Kegiatan eksplorasi merupakan kegiatan andalan di TK Pertiwi. Mengingat anak usia dini tidak membutuhkan asupan teori, maka proses pembelajaran didesain menggunakan kegiatan praktik pada lingkungan sekitar melalui kegiatan eksplorasi. Selain itu, kegiatan pembelajaran dengan alam juga dapat menstimulasi imajinasi anak agar terus berkembang. Berbeda jika pembelajaran hanya berpusat di dalam kelas, desain pembelajaran yang monoton dan kurang kreatif, secara otomatis kreativitas anak juga akan tumpul dan matilah imajinasi anak.

Pada proses kegiatan eksplorasi, tidak ada perbedaan perlakuan kepada anak-anak. Guru menganggap semua anak memiliki kelebihan dan kekurangan. Jika anak dianggap lebih menonjol dari pada teman lainnya, maka ia diminta membantu temannya yang kesulitan. Seperti ketika anak bingung membedakan gambar burung dan kupu-kupu, teman lainnya membantu dan menuntun temannya untuk mencari gambar yang sama persis dengan hewan yang ia pegang, seperti burung. Selain melatih perkembangan imajinasi dan kreativitas anak, nilai kerjasama teraplikasi di dalamnya. 


\section{Faizah}

\section{Bentuk kegiatan Eksplorasi di TK Pertiwi}

Ada beberapa kegiatan eksplorasi yang dilaksanakan di TK Pertiwi sebagai upaya pengembangan kreativitas anak-anak selama penulis melakukan penelitian. Dalam pelaksanaan kegiatan-kegiatan ekplorasi, guru menyesuaikan dengan tema-tema yang diajarkan pada setiap harinya. Berikut penulis analisis setiap kegiatannya:

Pertama, kegiatan bermain air. Tujuan bermain air ini adalah untuk meningkatkan kemampuan berpikir kreatif anak-anak sekaligus mengembangkan rasa ingin tahu anak tentang benda-benda dan kegiatan yang dilaksanakan. Adapun langkah-langkah kegiatan tersebut adalah; 1) guru menyediakan ember besar/ bak air, berbagai bentuk dan ukuran botol, ember, kaleng, plastik transparan, sedotan, gelas plastik transparan, kertas, pensil, dan pewarna. 2) melalui arena air dan baha yang ada, anak-anak melakukan kegiatan, seperti; a) membuat perahu-perahuan dari kertas kemudian diletakkan di atas air, b) memaskukkan air ke botol berbagai ukuran dan bentuk, tanpa tumpah, c) membuat kincir air. 3) guru membimbing dan membantu anak dengan mengajukan pertanyaan pada anak, misalnya; kesulitan apa yang dihadapi, apakah mereka membutuhkan bantuan guru dan lainnya.

Setelah kegiatan berakhir, guru mengajak anak-anak untuk masuk ke dalam kelas, siswa diminta maju ke depan menceritakan kegiatan yang dilakukannya, misalnya dalam kegiatan anak membuat kincir air ataupun perahu-perahuan, maka anak disuruh menceritakan proses awal hingga terahir (tidak dibatasi dengan gaya bahasa atau kedalaman penjelasan). Anak dibebaskan bercerita tentang kegiatan sebelumnya secara alamiah. Dalam arti, sesuai pemahaman mereka dan daya ingat mereka. Berikut adalah cara untuk membentuk kreativitas anak, di luar sekolahpun ia akan menerapkan bahkan mengembangkan kegiatan yang telah dilakukannya tadi.

Kedua, kegiatan bermain pasir. Tujuan dari kegiatan ini adalah meningkatkan kemampuan berpikir kreatif anak-anak, melakukan uji coba serta melatih keterampilan motorik kasar dan halus anak. Seperti yang penulis uraikan sekilas tentang kegiatan bermain pasir di atas, alat yang digunakan adalah ember kecil, sekop dan garpu mainan, berbagai bentuk cetakan. Pada permainan tersebut, anak-anak melakukan berbagai kegiatan yang disukai. Anak-anak bisa membuat bangunan sesuai dengan gambar yang ia bawa dan memilih cetakan yang sesuai dengan gambar, atau sesuai dengan keinginannya.

Anak-anak terlihat sedang membuat gunung, istana, gedung bertingkat, ada juga yang membuat kue. Semuanya bentuk-bentuk tersebut terbuat dari 


\section{Faizah}

pasir, yang sudah disediakan oleh guru. Guru juga menyediakan kaca pembesar dan anak mengamati tekstur pasir, dan menemukan jenis pasir besi yang menempel pada maghnet. Saat anak mengalami kesulitan, guru mendorong munculnya ide-ide kreatif anak dengan menegaskan bahwa anak dapat membuat apa saja yang diinginkannya. Pada tahap berikutnya, anak-anak akan lebih banyak mengembangkan kegiatannya sesuai dengan minat dan imajinasinya.

Ketiga, berkebun. Tujuan dari kegiatan berkebun adalah untuk meningkatkan kemampuan berpikir kreatif dan kritis, mengembangkan kemampuan pengamatan, ketelitian, belajar mandiri, dan rasa ingin tahu anak. selain itu, guru juga berharap, dari kegiatan berkebun ini dapat memupuk kesadaran untuk menanam sendiri tanaman-tanaman di kemudian hari dan melihat pertumbuhannya.

Langkah pertama yang dilakukan guru adalah menyediakan biji-bijian, pada saat itu, guru menyediakan biji kacang hijau, biji kedelai, dan beberapa bunga. Adapun anak-anak dianjurkan membantu guru menyiapkan tanah, pot dari botol aqua kosong serta lidi untuk mengukur pertumbuhan tanaman. Selanjutnya, guru dan anak-anak mengisi pot dengan tanah, kemudian masingmasing anak dianjurkan menanam biji-bijian dan diberi tanda. Ibu guru terlihat membantu anak dalam menuliskan nama dan tanggal penanamannya. Setiap hendak masuk kelas, anak-anak dianjurkan untuk mengurus tanamannya sendiri dengan memberikan jadwal untuk menyiramnya. Anak-anak juga mengukur pertumbuhan tanamannya dengan lidi.

Guru membiarkan anak-anak yang dengan sengaja malas menyiram dan merawat tanamannya. Jika beberapa tanaman layu, guru membawanya ke dalam kelas dan menjelaskan bahwasanya akibat dari tanaman yang tidak dijaga adalah kerusakan. Tanaman akan rusak dan akhirnya mati. Dari sanalah guru memberikan penjelasan bahwa untuk mendapatkan tanaman yang subur adalah dengan merawatnya. Berikutnya anak-anak dapat memperbaikinya.

Keempat, eksplorasi hewan. Eksplorasi hewan yang dilakukan guru dan anak-anak di TK Pertiwi adalah eksplorasi hewan ayam. Tujuannya adalah untuk meningkatkan kemampuan berpikir kreatif, mengembangkan kemampuan pengamatan, konsentrasi, ketelitian, dan rasa ingin tahu anak.

Guru membawa beberapa anak ayam dengan ukuran sedang, tidak terlalu kecil dan diletakkan di halaman sekolah. Siswa keluar dengan membawa kertas, pensil, pensil warna, lem, gunting, dan bahan pendukung lainnya. Melalui beberapa ayam tersebut, anak diminta menggambar ayam, mewarnainya, mengguntingnya dan menempelkannya pada kertas karton 


\section{Faizah}

ukuran besar. Anak-anak juga mengamati dan memberi makan ayam, mengukur panjang ayam, menimbangnya, membuat baju untuk ayam, dan beberapa kegiatan lainnya.

Anak dibebaskan berekspresi sesuai dengan keinginanya, asal tidak keluar dari tema pembelajaran. Melalui kegiatan tersebut, nantinya anak telah mendapatkan kesempatan dan pengalaman belajar mengamati hewan ayam. Anak tidak lagi asing dengan bunyi ayam, gambar ayam, makanan untuk ayam, ayam sehat dan tidak sehat dan bentuk dari ayam. Sehingga ketika anak di rumah, paham dan tahu bagaimana cara merawat ayam.

\section{Implikasi Kegiatan Eksplorasi Terhadap Perkembangan Kreativitas Anak di TK Pertiwi}

Di bawah ini penulis jabarkan beberapa implikasi yang menonjol dari hasil dokumentasi, wawancara dan observasi di TK Pertiwi, berikut penjabarannya: pertama, wawasan informasi anak-anak menjadi luas. Melalui beberapa kegiatan eksplorasi yang dilaksanakan oleh guru, membuat pengetahuan anak berkembang. Seperti contoh, anak yang belum mengetahui bagaimana cara merawat tanaman dan hewan, melalui kegiatan tersebut kini saat di rumah mereka mulai perhatian terhadap hewan dan tumbuhannya. Mengerti warna ayam, serta bentuk benda-benda lainnya. Jika anak hanya dijelaskan secara toeritis di dalam kelas, belum tentu anak mengerti bagaimana cara melakukannya. Masa kanak-kanak adalah masa bermain, dari bermain dan mengekspresikan dirilah pengetahuan akan mereka dapatkan.

Kedua, tumbuhnya rasa cinta terhadap lingkungan. Kini, anak-anak di TK Pertiwi mulai mengerti bagaimana caranya mencintai alam. Mereka mulai mengerti bagaimana menjaga lingkungan agar bersih, memelihara tumbuhan agar tidak mati dan lainnya. Hal tersebut dibuktikan dengan keseharian siswa sebelum masuk kelas, mereka dengan semangat memungut dedaunan yang jatuh dan membuangnya ke tempat sampah. Bungkus sisa jajan dan es yang dulunya berserakan di dalam dan luar kelas kini semakin berkurang. Meskipun perkembangannya tidak cepat, namun perlahan-lahan guru bisa merasakan jika ada perubahan pada anak-anak.

Ketiga, anak-anak menjadi lebih kreatif dan kritis. Bentuk kretif dan kritis anak terlihat ketika mereka mengumpulkan beberapa bungkus jajan, kertas dan plastik sisa jajan mereka. Kemudian mereka bertanya kepada guru kelas, fungsi dari pada sampah-sampah tersebut. Apakah hanya bisa dibuang tanpa dimanfaatkan. Pertanyaan-pertanyaan sederhana buat orang dewasa namun tidak untuk anak-anak. Akhirnya, guru bersama anak-anak 


\section{Faizah}

memanfaatkan kertas dan plastik tersebut menjadi hiasan ruangan kelas, seperti tirai dengan bentuk burung, gambar beberapa tanaman dan buah yang ditempel di dinding, serta bintang, bulan yang terbuat dari kertas dan plastik kemudian ditempel di dinding. Sekaligus beberapa kreativitas anak lainnya.

Keempat, menumbuhkan sikap kemandirian dan tanggung jawab anak. Kemandirian yang anak-anak miliki tentunya berbeda dengan kemandirian orang dewasa. Berangkat sekolah sendirian tanpa meminta orang tuanya menemanipun merupakan bentuk kemandirian anak. Membeli jajan sendiri tanpa merengek kepada guru dan teman untuk membelikannya juga sebuah kemandirian. Bekas tempat makan bekal sekolahnyapun mulai mereka cuci sendiri meskipun terkadang masih meminta guru untuk mencucinya. Bahkan, selesai bermain mereka mulai mengembalikan alat-alat mainanya ke tempat semula, tidak membiarkannya berserakan seperti sebelum-sebelumnya.

\section{Simpulan}

Berdasarkan penelitian yang telah dilakukan di TK Pertiwi Pateken Wonoboyo Temanggung tentang upaya mengembangkan kreativitas anak melalui kegaiatn eksplorasi maka dapat ditarik kesimpulan bahwa: konsep kegiatan eksplorasi di TK Pertiwi dilaksanakan sebagai pengganti kegiatan pembelajaran dan disesuaikan dengan tema pembelajaran. Kegiatan eksplorasi merupakan kegiatan andalan di TK Pertiwi. Mengingat anak usia dini tidak membutuhkan asupan teori, maka proses pembelajaran di desain menggunakan kegiatan praktik pada lingkungan sekitar melalui kegiatan eksplorasi.

Dalam pelaksanaan kegiatan-kegiatan ekplorasi di TK Pertiwi, guru menyesuaikan dengan tema-tema yang diajarkan pada setiap harinya. Adapun bentuk dari kegaiatan eksplorasi yang penulis dapatkan dari observasi seperti; berkebun, bermain air, bermain pasir-pasiran, eksplorasi hewan, dan eksplorasi panen padi. Melalui beberapa kegiatan tersebut, terbentuklah beberapa impilkasi, diantaranya; wawasan informasi anak semakin luas, tumbuhnya rasa cinta terhadap lingkungan, anak-anak emnjadi lebih kreatif dan kritis, sekaligus menumbuhkan sikap kemandirian dan tanggung jawab anak.

\section{Daftar Rujukan}

Hawadi, R. A. (2001). Kreativitas. Jakarta: PT. Grasindo.

Kemendikbud. (1994). Garis-garis Besar Program Kegiatan Belajar Taman Kanakkanak. Jakarta: Departemen Pendidikan dan Kebudayaan. 


\section{Faizah}

Rachmawati Yeni dan Kurniati Euis. (2017). Strategi Pengembangan Kreativitas Pada Anak, Usia Taman Kanak-kanak. Jakarta: Kencana Prenada Media Group. Semiawan Conny. (2002). Belajar dan Pembelajaran Pada Taraf Anak Usia Dini. Jakarta: PT Prenhallindo. 